\title{
FONÉTICA E FONOLOGIA NA FORMAÇÃO DE PROFESSORES INDÍGENAS
}

\author{
FONÉTICA Y FONOLOGÍA EN LA FORMACIÓN DE LOS DOCENTES INDÍGENAS \\ PHONETICS AND PHONOLOGY IN INDIGENOUS TEACHERS TRAINING
}

\author{
Wilmar da Rocha D'Angelis* \\ Universidade Estadual de Campinas - UNICAMP, BR
}

\begin{abstract}
RESUMO: Este texto discute as consequências de práticas de ensino de Fonética e Fonologia em cursos de formação de professores indígenas. Sustenta-se que o resultado de um treinamento em Fonética, em uma turma de professores indígenas em formação, costuma ser diferente do resultado que se obtém em uma turma de falantes nativos de português, formandos em Letras. Essa avaliação não se refere ao aproveitamento acadêmico, mas às representações ou crenças que se estabelecem ou são reforçadas nos professores indígenas. Aponta-se, como causa da diferença desses resultados, a história e a situação da escrita e das ortografias das línguas indígenas minoritárias, em comparação com a da língua oficial. Apontam-se, ainda, deficiências na formação de pesquisadores em Fonologia pelas Universidades brasileiras, que resultam em limitações das consultorias nos cursos em que essa matéria é "repassada" aos indígenas. Por fim, sugerem-se linhas para o trabalho com Fonética e Fonologia na formação de professores indígenas.

PALAVRAS-CHAVE: formação de professores indígenas; Fonética; Fonologia.
\end{abstract}

RESUMEN: Este documento analiza las consecuencias de las prácticas de enseñanza Fonética y Fonología en los cursos de formación de profesores indígenas. Se argumenta que el resultado de una formación en fonética, en una clase de maestros indígenas en formación, suele ser diferente de los resultados que se obtienen en una clase de hablantes nativos de portugués, que se forman en letras. Esta evaluación no se refiere a los logros académicos, sino más bien a las representaciones o creencias que se establecen o se refuerzan en los profesores indígenas. Se señala como causa de la diferencia de estos resultados, la historia y la situación de la escritura y de las ortografías de las lenguas indígenas minoritarias, en comparación con la de la lengua oficial. Se señala, también, deficiencias en la formación de investigadores en fonología de las universidades brasileras, lo que resulta en limitaciones en cuanto a consultorías se refiere en los cursos en los que esa materia es "repasada" a los indígenas. Por último, se sugiere lineamentos para el trabajo con fonética y fonología en la formación de profesores indígenas.

PALABRAS-CLAVE: formación de profesores indígenas; Fonética; Fonología.

ABSTRACT: This paper discusses the consequences of teaching practices of Phonetics and Phonology in training courses for indigenous teachers. It is argued that the result of training in Phonetics, in a class of indigenous teachers in training, is usually different from the result obtained in a group of native speakers of Portuguese, graduating in Letters. This assessment does not relate to academic achievement, but to representations or beliefs that are established (or reinforced) in indigenous teachers. We point out as the cause of the difference of these results, the history and situation of writing and spellings of languages indigenous minority, compared with the official language. We discuss also deficiencies in the training of researchers in Phonology by Brazilian universities, resulting in limitations of consultancies in the courses in which this matter is "passed on" to the natives. Finally, we suggest lines for work the Phonetics and Phonology in the training of indigenous teachers.

KEYWORDS: indigenous teacher training; Phonetics, Phonology.

\section{INTRODUÇÃO}

O presente texto resume muitas reflexões que tenho feito a partir de minhas experiências de participação em formação de professores indígenas em pelo menos meia dúzia de estados brasileiros desde meados da década de 1990, e do acompanhamento, ao mesmo tempo, de diversas outras experiências de formação.

Abro o texto com um breve tópico com respeito à "entrada" da Linguística no campo da formação de professores em nosso país, ou seja, à consagração da ideia de que a formação em Letras exige uma parcela significativa de conhecimentos linguísticos. A seguir, um tópico trata da específica relevância das áreas da Fonética e da Fonologia na formação de professores de português. O texto busca, com isso, demonstrar duas coisas: a primeira, que há fortes e importantes razões para que um curso de formação de professores de língua materna contenha um componente curricular das áreas de Fonética e Fonologia, apontando que esse entendimento, já há muito consagrado nos cursos de Letras, levou à inclusão de tópico semelhante em 
diversas licenciaturas para indígenas. ${ }^{1}$ A segunda é, justamente, destacar as diferenças de situações e resultados. Não é óbvio, como pareça, que o fato de se falar de "educação específica e diferenciada” 2 tem, como consequência necessária, o abandono dos modelos já experimentados no ensino regular superior.

$\mathrm{O}$ artigo entra, então, diretamente no campo da formação de professores indígenas. Essa parte abre-se com um tópico destacando as diferenças que se pode observar como resultado do treinamento fonético de falantes nativos de português, e de falantes nativos de línguas indígenas com pouca ou nenhuma tradição escrita. Esclareço, a propósito, que emprego aqui a expressão "falante nativo" para indicar quem tenha adquirido a língua em questão como língua materna (expressão comum na área da linguística aplicada em referência à "primeira língua”). Mais que isso, nos usos do presente texto, o "falante nativo" de uma língua está sendo igualado a "falante não-nativo" de outra língua, isto é, da $2^{\text {a }}$ língua. Dizendo de outro modo, estou assumindo que o falante nativo "típico" da língua indígena é alguém que adquiriu o português como $2^{\text {a }}$ língua. Existe, é verdade, a situação do chamado "bilinguismo simultâneo", em que se pode falar da ocorrência de "duas primeiras línguas”. Minha experiência indigenista de convivência (especialmente) com os Kaingang há mais de 35 anos, e minha experiência com formação de professores Kaingang há 15 anos mostra que tais situações são raras, ao menos para as gerações que até hoje tem ingressado na carreira docente.

Passo, então, a tratar propriamente do componente fonológico, iniciando por uma informação sobre o papel hegemônico que teve, na formação universitária brasileira, por décadas, a perspectiva da Fonêmica (introduzida no Brasil pelos membros do Summer Institute), e suas consequências, seja para as análises fonológicas realizadas de línguas indígenas (repercutindo nas definições de suas escritas) seja para a formação dos linguistas no país. Segue-se, então, um segundo tópico a respeito da formação de professores indígenas, focando dessa vez no componente fonológico. Quer se destacar ali, entre coisas, que Fonologia não é coisa simples, como às vezes parece ser tratada; e principalmente, quer se mostrar que problemas se produzem justamente pelo emprego da perspectiva Fonêmica, com todas as suas limitações e seu viés empirista, na formação de professores indígenas. Finalmente, dedico uma seção final a propostas (e relato de experiência) para o componente de Fonética e Fonologia na formação de professores indígenas.

\section{A LINGUÍSTICA NOS CURSOS DE LETRAS}

Há pouco mais de meio século a Linguística não tinha espaço nos cursos de Letras, isto é, nos cursos de formação superior de professores de línguas, seja materna, seja estrangeira. ${ }^{3}$ A única gramática, em tais cursos, era, obviamente, a gramática normativa, o que por si só já estabelecia a inexistência de espaço para uma abordagem sociolinguística. Era apenas tolerada uma dialetologia, desde que não se arvorasse em legitimar as chamadas variações diastráticas (de grupos sociais). ${ }^{4}$

A segunda metade do século XX assistiu uma grande mudança nesse quadro, nos cursos de Letras das universidades brasileiras. A partir das mudanças na Universidade de São Paulo, aos poucos se refletindo em outras universidades, a Linguística - em suas diversas áreas - foi ganhando mais e mais espaço e importância na formação de professores de língua materna. As mudanças reais foram acontecendo aos poucos, e na década de 1970 já era bastante aceita a ideia de que professores de língua estrangeira deveriam ter conhecimentos de linguística, particularmente de Linguística Aplicada. ${ }^{5}$ Porém, o debate sobre o papel e a relevância da Linguística para a formação do professor de língua materna seria travado efetivamente, apenas nos anos 80 .

Uma obra que é um marco do período, e uma das primeiras a tematizar explicitamente a questão, foi o livro A Linguística e o Ensino da Língua Portuguesa, do linguista Rodolfo Ilari (1985). No seu primeiro capítulo,

\footnotetext{
${ }^{1}$ Refiro-me, obviamente, às licenciaturas específicas que, entre suas modalidades de formação, incluem a área de Linguagem ou Letras (e são muitas, seguramente mais de uma dezena e meia em todo o país).

2 A propósito, já coloquei em questão, em mais de uma oportunidade, o valor dessa “máxima” (cf. D’ANGELIS, 2012).

${ }^{3}$ Refiro-me, aqui, à realidade brasileira. Nos demais países da América do Sul, acredito que essa realidade perdurou até bem mais recentemente.

${ }^{4}$ Possivelmente seria admissível, naquela abordagem, reconhecer a existência de particularidades como os jargões especializados de profissões das "pessoas de bem" (ou "de bens"): médicos, advogados, etc.

${ }^{5}$ Não por acaso publicam-se, na década de 70, duas traduções de obras que tratam exatamente dessas questões: As Ciências Linguísticas e o ensino de línguas, de Halliday et al. (Petrópolis: Vozes, 1974) e Teorias Linguísticas, Gramáticas e Ensino de Línguas, de E. Roulet (São Paulo: Pioneira, 1978).
} 
intitulado "O papel da Linguística nos cursos de Letras", o autor aponta, como "objetivo fundamental" do professor de português, "ampliar a capacidade de comunicação, expressão e integração pela linguagem da população atingida por seu trabalho” (ILARI, 1985, p. 9-10), e acrescenta:

Pensando o ensino de Letras nesse enfoque, somos levados a buscar os subsídios de várias disciplinas linguísticas, desde a fonética e a fonologia (como orientar, de outro modo, o processo de alfabetização?) até disciplinas que estudam a variação regional, social e estilística da fala, caracterizam suas funções, ou reconstituem o processo de sua aquisição, para não falar das teorias sobre leitura e compreensão. (ILARI, 1985, p.10).

Assumindo compreensão semelhante (não por mérito meu, mas por ter sido formado, como linguista, por mestres como Rodolfo Ilari e João Wanderley Geraldi' ${ }^{6}$ ), em um texto de 1999 sobre formação de professores indígenas, escrevi:

A capacitação em língua materna, em língua portuguesa e no ensino de línguas supõe instrumentos próprios da linguística que devem ser incorporados na formação do professor (noções fundamentais de fonética e fonologia, morfologia, sintaxe, semântica, linguística textual e sociolinguística). Essa é uma proposta há muito tempo defendida e justificada pela Linguística para a formação do professor de língua materna em nosso país. (D’ANGELIS, 2012, p.144). ${ }^{7}$

Não era, então, o lugar para maiores detalhamentos, uma vez que não ser tratava de um trabalho específico sobre a formação no campo da linguagem, questão que retomo agora. $\mathrm{O}$ presente texto não discutirá, porém, a questão da formação linguística em toda sua amplitude. Meu objetivo, aqui, é refletir sobre o ensino de apenas um par de componentes na formação de professores indígenas: a Fonética e a Fonologia. Antes, porém, faço um breve apanhado sobre a importância dessas áreas na formação do professor de língua (materna) portuguesa.

\section{FONÉTICA E FONOLOGIA NA FORMAÇÃO DO PROFESSOR DE PORTUGUÊS}

Em uma citação de Rodolfo Ilari, transcrita acima, aquele autor destacava o caráter indispensável das áreas da fonética e da fonologia na formação do professor de português, pelo menos para "orientar ... o processo de alfabetização". Esse, aliás, é o tema de um livro de outro linguista, Luiz Carlos Cagliari (1989): Alfabetização E Linguística. A propósito, o primeiro capítulo desse livro retoma, quase ipsis literis, o título da obra de Ilari, e se chama "A Linguística e o ensino de português". Nele, entre outras considerações importantes, Cagliari afirmava:

Muitos professores atribuíram os fracassos da escola mais recente à intromissão da Linguística nas salas
de aula. A Linguística tem por objetivo o estudo da linguagem e, por conseguinte, não é por si um
método de ensino. [...] O uso da Linguística no ensino de português tem que ser planejado em conjunto
por linguistas e professores de português, com a colaboraça de pedagogos, psicólogos etc. […] O
professor de português tem que ser um profissional competente, tem que conhecer profundamente a
língua portuguesa. Como ele pode ensinar o que não sabe? (CAGLIARI, 1989, p.41).

O fato é que, mesmo que o professor de português (o profissional formado em Letras) não seja ou não venha a ser o responsável pela alfabetização nas séries iniciais do Ensino Fundamental, ele terá que lidar com a escrita dos seus alunos diariamente, e por isso é indispensável que tenha uma formação adequada, que lhe permita compreender, por exemplo, os chamados "erros" ortográficos de seus alunos. ${ }^{8}$ Essa formação inclui, necessariamente, uma compreensão da distinção entre registro fonológico e registro fonético, um entendimento das características específicas do sistema ortográfico da língua portuguesa (em boa parte, fonologicamente motivado, mas também, em parte, morfológica, etimológica e - ainda - foneticamente motivado), e uma compreensão do panorama sociolinguístico brasileiro, considerando as múltiplas variantes dialetais com que convivemos.

\footnotetext{
${ }^{6}$ De João Wanderley Geraldi, veja-se Portos de Passagem (São Paulo: Martins Fontes, 1991), obra imprescindível para quem atua no campo da formação de profissionais da linguagem.

7 Tex to de 1999, apresentado e distribuído em Seminário organizado pelo MEC, publicado originalmente na revista Em Aberto, do INEP, em seu n. 76 (2003).

${ }^{8}$ Na citada obra de Cagliari, o capítulo 3 (A escrita) traz uma excelente introdução a essa questão.
} 
Para exemplificar a importância dessa formação para os professores de língua materna, sintetizo uma experiência que vivi (e que ainda espera por um registro detalhado).

Em 2004 fui convidado pelo Núcleo Regional da Secretaria de Educação, de uma cidade do Sudoeste do Paraná, para ajudar os docentes de língua portuguesa em suas dificuldades no ensino, ministrando uma atividade de formação que recebeu, da coordenação do Núcleo, o eloquente título de "A importância da emancipação humana através da linguagem: ensino de língua materna em situação de contato linguístico". O principal "problema" - segundo os que me convidaram - era a dificuldade dos professores no ensino de português para crianças e jovens descendentes de imigrantes, pela interferência de uma outra língua, familiar, na fala e na escrita deles em português. Em função disso, definiram, como principal objetivo dessa formação:

Perseguir formas adequadas de trabalho com a língua Portuguesa em situação que envolve contato linguístico e em contexto sociolinguístico com presença de variedades regionais marcadas (em razão da influência de outras línguas europeias de comunidades descendentes de grupos imigrantes), objetivando a aquisição, pelos alunos, das formas próprias do dialeto padrão.

Trata-se, de fato, de uma região que sofreu processo de colonização por descendentes de imigrantes principalmente de origem alemã, italiana e polonesa (a maioria, transmigrados de Santa Catarina e do Rio Grande do Sul) -, sobretudo a partir da década de 1950.

O público alvo era constituído de uma centena e meia de professores de português, atuantes no Ensino Fundamental e Médio, em escolas urbanas e rurais no município. Programei a atividade de formação em duas etapas (ou encontros), sendo que entre a primeira e a segunda todos os professores desenvolveriam, com seus alunos, uma mesma atividade de produção textual. Dessa produção, uma amostra me seria enviada (em torno de 300 textos), e sobre ela é que desenvolveríamos o trabalho de análise, no segundo encontro. Estava ciente de que, não fosse assim, os professores não abandonariam suas falas estereotipadas, seus discursos pré-construídos sobre os problemas e incapacidades dos seus alunos.

No primeiro encontro tratei de algumas noções fundamentais de sociolinguística e linguística aplicada, pertinentes ao tema proposto, tais como: língua, dialetos, variantes e registros; preconceito linguístico; variação e mudança; contato linguístico etc. Produzimos, também, em grupos, um estudo sobre a história e a realidade linguística da cidade e sua região, e tratamos de metodologias para um programa de investigação sobre relação entre as variedades regionais e as dificuldades de produção oral e escrita dos alunos. Finalmente, definimos a tarefa que seria realizada, para colhermos o material que serviria à análise no segundo encontro, três meses depois.

Recebi, como previsto, mais de trezentos textos enviados como amostra, vindos de todos os professores participantes da formação, e me debrucei sobre duzentos deles, identificando e contabilizando cada tipo de problema de escrita encontrado. E o resultado da análise, compartilhada com os docentes no segundo encontro, revelou que o maior problema dos alunos seguramente não era a influência de uma outra língua (materna). Os problemas ortográficos atribuíveis a esse fator ${ }^{9}$ apareceram em quarto lugar, praticamente empatados com os problemas de segmentação (hipo ou hiper-segmentação) ${ }^{10}$, com cerca de $9 \%$ cada um, do total de "desvios ortográficos" contabilizados. Para ser mais preciso, $9 \%$ foram os "erros" atribuíveis ao uso, pelo aluno, ou de uma outra língua materna que não o português (o alemão, por exemplo) ou de um dialeto distinto do chamado "português padrão" (fosse ele um dialeto surgido do contato de uma língua de imigrantes com a língua portuguesa, fosse ele um dialeto não-padrão do português ${ }^{11}$ ).

Já os principais problemas detectados foram:

(i) "trocas de letras" (axam, acontessa, aprocimar, alto-estima, viros, insegura...), a maior parte delas justificáveis pelas alternativas possíveis existentes no sistema ortográfico (por ex.: "s" ou "z" podem representar o som [z] entre vogais; "ss" ou "ç" podem representar o som [s] no mesmo contexto; etc.) e outras tantas por hiper-correção;

\footnotetext{
${ }^{9}$ Por exemplo: aborecer, amarado, garas, pusca, covernos, critam, barrulho, corragem etc.

${ }^{10}$ Por exemplo: enbusca, pormais, sejogam, a conteseu, a penas, de mais, em quanto etc.

${ }^{11}$ Incluiram-se, portanto, nessa 'conta', a formas como: pobrema, irreversivre, veve (vive), vever etc.
} 
(ii) "acentuação gráfica" (dadivas, dramatico, indice, possivel, avos, resolve-los, alguem...), a metade delas por omissão do acento em proparoxítonas;

(iii) "transcrição fonética" (acabão, baliou, dizilusão, dizilusão...).

Esses três tipos de desvios ortográficos responderam, respectivamente, por 32\%, 26\% e 14\% dos problemas encontrados, ou seja, juntos somaram $72 \%$ dos "erros" dos alunos.

A principal lição a tirar, desse episódio, não era, pois, que a influência de uma língua ou dialeto familiar fosse o grande vilão do "mau" desempenho dos alunos de português naquela pequena cidade paranaense. A importante lição foi que os professores de português, em sua maior parte, não estão preparados para avaliar e reconhecer a origem das dificuldades de escrita dos seus alunos. É aqui que se revela a falta de uma formação linguística adequada ao professor de português, particularmente nos campos da Fonética, Fonologia e Sociolinguística.

Para concluir esse tópico, quero destacar, portanto, que nos cursos de Letras que formam professores de português é mais do que recomendável que os alunos recebam uma formação básica em Fonética e Fonologia. O professor de português tem que ter clareza, por exemplo, de que:

- a ortografia do português é resultado de um longo processo histórico, de uma língua que vem sendo escrita há 800 anos, e que mantém nessa ortografia muitas coisas que se explicam pela herança e valor histórico. Por exemplo: o "h" em palavras como homem, humano, hospital, humilde e tantas outras, mantém-se por um conservadorismo, e sua motivação é apenas etimológica (ou seja, diz respeito à origem latina das palavras), já que esse "h" não tem valor fonológico nem fonético. Pela mesma razão, temos centenas de palavras escritas com "ç" e outras centenas com "ss", mas representando o mesmo som; o fato é que a língua portuguesa distinguia essas duas formas na sua fala (eram pronunciadas de modos bem distintos) pelo menos até o século XVI ou XVII, e por isso também as diferenciava na escrita. Essa diferença desapareceu na fala (hoje em dia, "paço" e "passo" têm exatamente a mesma pronúncia), mas se manteve a diferença na escrita (o que também tem, obviamente, sua utilidade).

- pela dispersão geográfica das populações que o falam, e também pelo grande número desses falantes, o português conta com dezenas de dialetos. ${ }^{12}$ Isso faz com que haja muitas pronúncias para uma mesma palavra, embora a escrita seja unificada. Ou seja, uma determinada forma escrita pode ser lida de diversas maneiras, porque o português conta com muitos dialetos. Por exemplo: (a) tomate : [to'matfi], [tu'mat $\mathrm{i} i]$, [tu'mati], [to'mate]; (b) diferente : [d]ife'rẽnt $\left.\int \mathrm{i}\right]$,

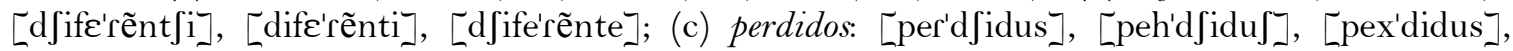

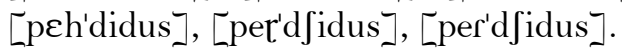

- não existe "uma forma certa" de pronunciar as palavras em português; cada dialeto tem uma história própria, e é tão legítimo quanto os outros. Nos exemplos acima, se alguém dissesse que para a palavra tomate a pronúncia "certa" é a quarta, [to'mate], teria que explicar porque, então, essa é a forma menos usada pelos falantes de português: no Brasil, com mais de 190 milhões de falantes nativos do português, provavelmente menos de $5 \%$ são os que pronunciam [to'mate]. E ainda teria que explicar porque, nessa minoria, há muitos analfabetos, o que significa que a tal "pronúncia certa" não tem nada a ver com estudo ou maior escolarização. E, por fim, teria também que explicar porque é que as mesmas pessoas que falam [to'mate] não pronunciam a palavra diferente como [dife'rẽnte], mas sim, [d]ife'rẽnte]. Se a forma "certa" de falar fosse a que mais se aproxima da escrita, essas pessoas não deveriam usar a forma [ $\left.\mathrm{d} \int \mathrm{i}\right]$ ou [ $\left.\mathrm{t} \int \mathrm{i}\right]$, mas apenas [di $]$ e $[\mathrm{ti}]$.

- existem muito poucas regras ortográficas, e a maior parte do conhecimento da ortografia vem do hábito de leitura, de "acostumar-se" com a forma das palavras. Por exemplo: não existe regra para explicar porque usar "ç" em caça, em lugar de "ss"; ou porque usar "ss" em massa, em lugar do "ç"; porque é que exército se escreve com "x" e não com "z", e máximo se escreve com "x" e não com "ss"; ou porque achar se escreve com "ch", mas mexer se escreve com "x".

\footnotetext{
${ }^{12} \mathrm{O}$ português coloca-se entre as 10 línguas mais faladas no mundo. Está em $8^{\circ}$ lugar, pelo número total de falantes (ou seja, falantes nativos + falantes como $2^{\text {a }}$ língua), com cerca de 285 milhões de pessoas; e em $6^{\circ}$ lugar se computados apenas os falantes nativos, com algo entre 260 e 270 milhões.
} 
- se a criança escreve "voutar" (em vez de voltar), "auma” (em vez de alma), "saibão” (em vez de saibam), ela está escrevendo do modo como ela pronuncia as palavras, possivelmente porque faz a hipótese de que a escrita é uma forma de transcrição fonética da fala. O professor é quem precisa reconhecer isso e saber ensinar ao aluno que a escrita não é isso. ${ }^{13}$

\section{NÃO FAÇA DO PROFESSOR INDÍGENA UM FONETICISTA !}

A partir de 1999, quando o Conselho Nacional de Educação definiu a responsabilidade dos Estados da Federação na execução da educação escolar para as comunidades indígenas, incluindo a tarefa da formação dos professores indígenas, cresceram vertiginosamente as ações de formação inicial, que em muitos Estados foram acompanhadas de uma diminuição proporcional das ações de formação continuada. Ao mesmo tempo, a partir de 2000 ampliaram-se as ações de formação de professores em magistério de $2^{\circ}$ grau (Ensino Médio), e proliferaram, igualmente, as Licenciaturas Específicas para indígenas em Universidades públicas e (em uns poucos casos) comunitárias.

Muitos consultores e docentes de cursos de formação de professores indígenas, possivelmente percebendo a importância das questões colocadas acima, julgam indispensável ministrar Fonética e Fonologia naqueles cursos de formação, seguindo a tendência dos cursos de Letras das melhores Universidades do país. ${ }^{14}$ Aqui, porém, é que começam os problemas que motivaram a proposta do presente texto.

Em primeiro lugar, quero destacar porque o resultado de um treinamento em Fonética articulatória pode ser diferente, em uma turma de professores indígenas em formação, do resultado que se obtém em uma turma de falantes nativos de português, formandos em Letras.

Em segundo lugar, quero argumentar que há deficiências comuns na formação de pesquisadores em Fonologia nas Universidades brasileiras, que resultam em limitações nas consultorias e nos cursos em que essa matéria é "repassada" aos indígenas. Mas também quero apontar que isso não explica todos os problemas.

Comecemos pelo primeiro ponto.

Os alunos de Letras, falantes nativos de português, com longa prática de escrita (após mais de dez anos de escolarização e práticas de leitura), facilmente compreendem as diferenças e a distância existente entre as formas da escrita e as formas da fala na língua portuguesa. Para se tornarem escritores proficientes tiveram que compreender claramente isso, ou não teriam chegado - a maior parte deles - ao ensino superior. Essa não é a experiência do indígena, aluno de uma Licenciatura específica, também formando em Letras. ${ }^{15}$

Ocorre que as línguas indígenas brasileiras não desenvolveram, ainda, uma tradição de escrita. Trata-se de um processo recente, ainda pouco registrado, e com pouco tempo para gerar algum conhecimento acumulado sobre seus percursos. ${ }^{16} \mathrm{O}$ que pretendo destacar, aqui, é o fato de que, na maioria esmagadora dos casos, as escritas das línguas indígenas guardam "pouca distância” da língua falada.

$\mathrm{Na}$ verdade, isso precisa ser melhor esclarecido, porque existem alguns complicadores envolvidos, e nisso reside uma parte das deficiências na formação dos próprios consultores. Mas vou deixar esses esclarecimentos mais complexos para o tópico seguinte ( $O$ drama da Fonologia (indígena) no Brasil), e por hora vou tratar de algo mais simples de se entender, mas igualmente importante: a maioria das línguas indígenas mudou muito pouco desde que sua escrita foi estabelecida.

Quando uma língua possui uma longa tradição de escrita (como é o caso do português, do francês, do inglês, etc.), enquanto a fala se transforma na passagem das gerações, a escrita pode permanecer inalterada durante

\footnotetext{
${ }^{13}$ Com frequência, os professores primários (por má preparação) alimentam nos alunos essa ideia da escrita como "transcrição fonética”, quando fazem seus "ditados" mais ou menos assim: "O mEninO foi AA casa da mEninA, feliZ, com seu cavalO”.

${ }^{14}$ Muitas vezes, uma outra motivação está por trás dessa prática, mas voltarei a isso adiante.

${ }^{15}$ Refiro-me às Licenciaturas especialmente criadas para clientela indígena, em um bom número de Universidades brasileiras, a partir do início dos anos 2000.

${ }^{16}$ Ver W. D’Angelis, Como nasce e por onde se desenvolve uma tradição escrita em sociedades de tradição oral?. Campinas: Ed. Curt Nimuendajú, 2007.
} 
séculos. Por isso, como já vimos, o português guarda marcas da origem latina de muitas palavras (o "h" inicial), e guarda marcas do tempo em que a língua portuguesa distinguia um som "ç" de outro som escrito com "ss" (cf. EDELWEISS, 1947). Há muitas outras coisas assim, que vão se cristalizando na ortografia da língua, enquanto a língua falada, mais dinâmica e pouco controlável, vai se alterando.

Pela mesma razão, uma língua como o francês escreve palavras como roi, loi, bois, trois, droit enquanto sua pronúncia delas é: [ruá], [luá], [buá], [truá], [druá]. ${ }^{17}$ Como mostrou o próprio Ferdinand de Saussure, no século XI as palavras para "rei" e "lei" (e as demais da série acima) eram pronunciadas e escritas exatamente assim: rei [rei], lei [lei]. No século XIII a pronúncia mudou para [roi] e [loi], e a escrita passou a ser roi, loi. No século seguinte a pronúncia já havia mudado de novo, para [roe] e [loe], mas a escrita não foi alterada: continuaram a escrever roi, loi. Finalmente, já no século XIX, a pronúncia tinha se tornado [ruá] e [luá], como é hoje, mas a escrita continuou sem alterações (Cf. SAUSSURE, [1916] 1974, p.37). No começo do século XX, de certo modo toda a França participou de um grande debate em torno de uma (necessária) reforma ortográfica; as posições se tornaram, no entanto, tão discordantes e tão irredutíveis, que todo o movimento resultou em um grande fracasso, e praticamente nada foi revisto (Cf. MARTIN, 1996).

O caso da ortografia das línguas indígenas apresenta uma situação um tanto particular, e diferente: com exceção da língua guarani, que teve uma primeira escrita fixada pelos missionários espanhóis já no século XVII, e o nheengatu (ou "Língua Geral Amazônica"), cuja escrita foi sendo fixada e ajustada desde o século XVII até o final do século XIX, as demais línguas indígenas sobreviventes tiveram ortografias definidas apenas no século XX. E se nos referirmos às ortografias efetivamente empregadas para alfabetizar crianças indígenas e, a partir disso, empregadas pelos próprios indígenas para produzir seus textos, então nosso recuo não chegará nem à metade do século XX: foi somente a partir da década de 1960 que diversos empreendimentos missionários evangélicos - e, em parte, ações oficiais (da FUNAI) aliados àqueles ${ }^{18}$ deram início a práticas de alfabetização na língua indígena e, como sua máxima realização, à tradução do Novo Testamento para tais línguas. ${ }^{19}$ Ainda assim, em geral se passaram duas ou três décadas até que, nas comunidades em que tais ações se iniciaram, os indígenas efetivamente começassem a empregar tal escrita para produzir materiais próprios, em suas línguas. E no caso do guarani, mencionado acima como uma exceção, também não se teve exatamente continuidade de uma coisa na outra; a escrita missionária foi se tornar, aos poucos, a escrita do guarani paraguaio (GP), mas a maior parte das comunidades indígenas guarani acabou adotando, na segunda metade do século XX, ortografias específicas, ainda que guardando muitos elementos em comum com a do GP.

Ademais, a definição das ortografias dessas línguas indígenas foi feita, quase sempre, com base em noções da Linguística, mesmo quando elaboradas por missionários evangélicos. ${ }^{20}$ Dessa forma, pelo menos na intenção, a maior parte das ortografias de línguas indígenas brasileiras criadas a partir da segunda metade do século XX tem uma motivação fonológica. Porém, mesmo quando elas falham na motivação fonológica (em razão das limitações do modelo teórico empregado), a ortografia criada mantém relação muito próxima com a fala (e até "mais") porque muitas vezes incorpora material fonético ${ }^{21}$.

Considerando o que foi dito, entende-se que a maioria das línguas indígenas cuja ortografia foi estabelecida com base em estudo linguístico há menos de 30 ou 40 anos (e várias delas, há menos de 10 ou 15 anos) não apresentem, ainda, tal distanciamento da fala em relação às formas ortográficas que favoreça ou exija do falante alfabetizado nativo a compreensão dessa diferença. O que ocorre é, antes, o contrário: a impressão de uma "transparência" entre a fala e a escrita, alimentando a ideia de que a escrita transcreve (fielmente) a fala.

\footnotetext{
${ }^{17}$ Significam, respectivamente: "rei, lei, madeira, três, direito”. Emprego, aqui, transcrições latas, simplificando a representação do "r".

${ }^{18}$ Refiro-me à cooperação da FUNAI com o Summer Institute of Linguistics (cf. D’ANGELIS, 2004a; 2012 - cap.16).

${ }^{19}$ Vale destacar que em boa parte (talvez maioria) das línguas em que os evangélicos traduziram textos bíblicos, os indígenas - mesmo 'convertidos' - raramente empregaram essas traduções na sua relação com a religião cristã.

${ }^{20}$ Com a atuação do SIL (Summer Institute) no Brasil desde o final da década de 1950, muitas línguas indígenas foram objeto da ação de membros (missionários) dessa instituição (ou por ela apoiados), empregando, para a definição ortográfica, uma prévia análise fonológica da língua baseada na Fonêmica (no próximo tópico darei algum esclarecimento sobre isso).

${ }^{21}$ Quem não compreenda exatamente o sentido dessa passagem pode, ao menos, concluir, a partir disso, que estabelecer a relação entre formas fonéticas, formas fonológicas e formas ortográficas não é uma operação trivial. E ao dizer que uma determinada escrita ortográfica pode estar até "mais" próxima da fala, se ela incorpora material fonético, isso não significa que se trata de uma escrita melhor (de nenhum ponto de vista), mas quase sempre o contrário (exceções seriam os casos em que a escrita da língua indígena não se destina a falantes nativos; cf. D’ANGELIS, 2005).
} 
Não se pode atribuir apenas a falhas da alfabetização a ocorrência dessa concepção entre crianças alfabetizandas ou recém-alfabetizadas. A escola e o ensino equivocado podem, sim, "sacramentar" e perpetuar essa ideia errônea, mas a origem dela está nas qualidades do próprio sistema de escrita alfabético, em seu princípio fonográfico: as letras representam fonemas, e suas combinações, as sílabas a serem pronunciadas. Embalados por essa crença, e se a ortografia de sua língua tiver sido, realmente, bem elaborada (segundo os princípios de uma escrita fonológica), o falante nativo não terá dificuldade ou dúvida na escrita de qualquer palavra, bastando sua intuição para escrevê-la. Quantos falantes nativos de português, alfabetizados, não gostariam de gozar um tal privilégio! 22

A propósito, escreveu o grande fonólogo russo, Nikolay Trubetzkoy ([1933] 1981, p.33):

É evidente que, quando um sistema de escrita acaba de ser criado ou adaptado a uma língua, e ainda não se acha sobrecarregado por vestígios reputados como históricos, escreve-se "o que se crê pronunciar", de tal maneira que a escrita desta época reflete o sistema fonológico da língua dada.

É aqui que os problemas do ensino ou treino fonético, com falantes nativos da língua indígena, em cursos de formação de professores, começam a ganhar forma. Convencidos (ou melhor, iludidos), a partir da mencionada experiência, do caráter "transparente" da escrita em relação à fala, os professores indígenas, colocados diante da realidade fonética (à qual não tinham acesso antes, porque a intuição do falante nativo não ultrapassa o nível do sistema fonológico), são tentados a pensar que sua escrita ortográfica não está suficientemente boa, porque não registra os fatos fonéticos tal como acontecem na fala. Some-se a isso o apelo que a realidade empírica exerce sobre as pessoas em geral, sobretudo quando lhes parece o resultado de um alcance possibilitado por uma nova ferramenta, da qual não dispunham em sua cultura (como um microscópio, um binóculo ou um telescópio). Nesse sentido, o uso de fonética instrumental, nesses cursos, pode ser ainda mais pernicioso.

Lembro-me de minha experiência em uma comunidade ashaninka, em meados da década de 1990, quando fui convidado a ajudá-los na definição de uma ortografia (cf. D’ANGELIS, 1994). Um dos participantes ativos desse trabalho, alfabetizado e bastante letrado em português, me perguntava, quase insistentemente: Então nós não vamos ter o "bê", o "dê" e o "guê"? Referia-se às letras que, no alfabeto deles, não teriam utilidade, uma vez que a língua ashaninka não distingue, nas consoantes obstruintes (oclusivas ou fricativas), surdas de sonoras; ou seja, não distinguem "p" e "b", "t" e "d", "s" e "z", etc. Os falantes nativos não alfabetizados em português não tinham essa dúvida, e não tiveram o menor problema em empregar, na escrita, apenas a letra "p", por exemplo, apesar de que, na fala, sua pronúncia pudesse variar, em palavras como "opẽpe" ( “opẽmbe”), “nopãte” ( “nupãnde”), "ashenĩka” ( "ashenĩnga”), etc. O mencionado falante alfabetizado em português, seja por sua prática oral dessa língua, seja por sua prática de leitura, aprendeu a distinguir $p \times$ $b$, $t \mathrm{x} d, s \times z$, etc., e isso lhe permitia 'ouvir', na sua língua, diferenças que seus parentes, sem aquela experiência, não ouviam, isto é, não percebiam. Isso significa que tais diferenças, embora fisicamente reais (por isso, passíveis de percepção para um ouvido treinado, mesmo que seja o treino de outra língua), são fonologicamente inexistentes na língua.

Voltemos, então, ao professor indígena, convencido, por sua experiência, de que a escrita reproduz a fala. A ele se ministra um treinamento fonético, para aprender a reconhecer as articulações distintas de sons. Ele facilmente se convence da realidade (empírica) do seu idioma, e com frequência, passa a advogar mudanças na escrita, para torná-la mais fonética (mas que ele entende ser, por isso, mais "de acordo" com a língua). E quando os recursos para isso já existam no próprio alfabeto, a escrita do próprio professor se torna cada vez mais fonética. Ilustro com um exemplo de professores kaingang. Sua língua distingue, fonologicamente, entre outras, as vogais /o/ e /u/. Não se pode confundir ou trocar essas vogais em pares de palavras como, por exemplo, jor $\mathrm{x}$ jur, son $\mathrm{x}$ sun, sor $\mathrm{x}$ sur, toj $\mathrm{x}$ tuj, etc. Mas existem palavras em que se percebe uma certa oscilação na pronúncia, porque não existe um par em contraste, como é o caso da palavra to (em direção a, em relação a). Assim sendo, na fala, conforme a frase ou o elemento que essa palavra acompanha, a sua pronúncia às vezes soa [to], às vezes soa [tu]. Passando a escrever com atenção nas formas fonéticas, observamos que um mesmo professor, em seus textos, algumas vezes escreve "to", e outras vezes, "tu".

\footnotetext{
22 Pode-se dizer até mais que isso: se não houver interferências da prática de escrita em outra língua (quando acontece de indígenas terem sido alfabetizados, primeiro, na língua oficial do país, seja o português, o espanhol, o inglês ou qualquer outra), a intuição do falante nativo, ao escrever, se torna o melhor fiel da balança para confirmar ou exigir a revisão de uma ortografia definida por um pesquisador não-nativo. Veja-se, a propósito, o texto de Edward Sapir, em que ele relata como entendeu a "distância" entre o componente fonético e o componente fonológico, a partir da escrita intuitiva de um indígena Paiute (SAPIR [1933] 1981).
} 
Um outro exemplo, também do kaingang: por um processo fonológico frequente, uma consoante nasal palatal " $n h$ " final de uma palavra, seguida de uma palavra iniciada por consoante oclusiva surda dental " $t$ ”, faz, do encontro dessas duas consoantes, uma única consoante fricativa: "s" $=\left[\int\right]$. Se o verbo "tãnh", por exemplo, for precedido do pronome "inh" como seu Objeto Direto ("bateu em mim"), a sequência "inh tãnh" produzirá, na fala corrente, [ifãn]. Há professores que, em qualquer desses casos, escrevem foneticamente: “isãnh”. ${ }^{23}$

A isso se acrescenta outro fato: diferentes professores, de diferentes aldeias, passam a identificar onde está a diferença entre as falas de uma e outra comunidade. Ou seja, aquelas diferenças dialetais de pronúncia, que eram já percebidas (e muitas vezes, imitadas, mesmo que para fins jocosos), nesse novo contexto ganham possibilidade de descrição e de identificação do traço que as produz. Disso podem resultar, entre outras, duas atitudes: um discurso em defesa de uma língua (ou dialeto) como "mais certa" (sempre na confrontação da oralidade com a ortografia) de uma aldeia em relação a outras; ${ }^{24}$ ou um discurso em defesa do registro escrito das diferenças (ou seja: que cada aldeia adote uma escrita, conforme seu modo de falar). Politicamente, por razões históricas várias, essa última pode até ser uma solução justificada para algumas situações particulares (Cf. D’ANGELIS, 2005), mas quando ela é tomada em função de um entendimento equivocado do que sejam as relações dialetais, ou as relações entre fala e escrita, então temos um problema que tende a gerar outros, em cadeia.

Mencionei, ao longo desse tópico, a realidade dos professores indígenas em formação, que são falantes nativos das línguas étnicas de suas comunidades. Há, porém, o caso, dos professores em formação que não são falantes nativos da língua indígena (alguns, inclusive, sequer são falantes não-nativos). ${ }^{25}$ Os que se enquadram nesse perfil não constituem, certamente, uma homogeneidade; há os que, sendo falantes nativos de português, igualmente tiveram, ao longo de sua vida escolar, um contato limitado com os usos da escrita, e há os que revelam vasta experiência e competência no domínio da leitura e da escrita em língua portuguesa. O comum é que, também nesses casos, o contato prévio com a escrita em língua indígena seja pequeno e, muitas vezes, nenhum. ${ }^{26}$ Com essas pessoas, alguns dos efeitos problemáticos do treinamento fonético não se produzem, ou são inócuos (e não cabe falar, no caso, em efeitos sobre a "intuição do falante", porque nesses casos ela não existe com respeito à língua indígena). Não se deve desconsiderar, porém, as dificuldades maiores ainda, de trabalhar com falantes nativos e não-nativos da língua indígena no mesmo espaço formativo, ainda que tais dificuldades devam ser encaradas como oportunidades igualmente instigantes para o processo de formação, e dessas situações se podem extrair excelentes resultados.

\section{O DRAMA DA FONOLOGIA (INDÍGENA) NO BRASIL}

O campo dos estudos acadêmicos das línguas indígenas ganhou grande impulso e incremento nas universidades brasileiras a partir da década de $1980 .{ }^{27} \mathrm{E}$ como o nível fonológico é visto como o primeiro nível de análise indispensável para o conhecimento de uma língua indígena, proliferaram, de imediato, os estudos de descrição fonológica de línguas indígenas brasileiras.

Por outro lado, é inegável que o campo dos estudos em Fonologia, no Brasil, ampliou-se quase que vertiginosamente, também a partir do final do século XX. ${ }^{28}$ Influiu nisso, particularmente, a efervescência

\footnotetext{
${ }^{23}$ Existem, é verdade, situações “cristalizadas”, pelo uso muito frequente. É o caso das formas de Sujeito pronominal de $1^{\text {a }}$ pessoa singular, "isỹ” e "isóg”, resultantes de "inh + tỹ” e "inh + tóg”. No entanto, mesmo nesses casos, como na pronúncia de fala rápida o "i” é bastante reduzido, muitos professores já escrevem - foneticamente - apenas "sỹ" e "sóg”. Certamente as reduções são possíveis e historicamente se produzem, como de "vossa mercê" o português passou a "vosmecê" e, finalmente, a "você". O que me parece é que, no caso, os professores kaingang já estão querendo legitimar, ortograficamente, algo semelhante a passarmos, no português, à grafia apenas de "cê” (no lugar de "você”).

${ }^{24}$ Não esquecer que Ursula Wiesemann, apesar de tratar com falantes de diversos dialetos, construiu sua proposta ortográfica a partir do dialeto de Rio das Cobras, o que deu a esse dialeto um caráter de "língua oficial" da escrita. Veja-se um questionamento, por exemplo, em D’Angelis (2007).

${ }_{25}$ Tive experiências, como formador e como consultor de comunidades indígenas, em grupos ou em turmas com alunos com esse perfil, tanto com kaingang como com guarani.

${ }^{26}$ Registre-se que, mesmo entre professores falantes nativos de kaingang, encontrei situações (não propriamente raras) de professores em formação que pediam autorização para escrever seu texto primeiramente em português, para depois 'traduzi-lo' ao kaingang. Obviamente tratamos de mostrar a inadequação disso, e estimulá-los a superar essa dificuldade, tendo sucesso quase sempre. Mas o fato mostra que sua relação com a escrita dependia dos modelos da língua portuguesa.

${ }^{27} \mathrm{O}$ ano de 1982 marca o cancelamento do último convênio que o Summer Institute of Linguistics manteve como uma Universidade brasileira; infelizmente, isso não representou o fim da influência do SIL na formação de pesquisadores em línguas indígenas, como veremos adiante.

${ }_{28}$ Talvez se possa situar o início desse processo, no Brasil, em meados dos anos 90.
} 
de novas (e, muitas, supostamente novas) abordagens no campo da Fonologia, sobretudo a partir das chamadas Fonologias não-lineares. ${ }^{29}$ A aplicação de alguns desses modelos, seja à língua Portuguesa, seja a línguas indígenas, foi o responsável pelo crescimento dos estudos na área.

Infelizmente, porém, no campo da fonologia de línguas indígenas, o grande onipresente é, ainda hoje, o modelo da Fonêmica, de Kenneth Pike, difundido no Brasil por seus seguidores do mencionado Summer Institute (entidade da qual aquele linguista foi o presidente por quase 40 anos). Não repetirei aqui a análise do "alinhamento pró-Estados Unidos" da Fonologia no Brasil, que já historiei em outro lugar (ver D'ANGELIS, 2004b), e cuja consulta tomo a liberdade de recomendar. Mas destaco o problema fundamental que essa orientação (prática, e bem pouco teórica) produz.

Todo o interesse do aparato da Fonêmica - cujos procedimentos estão expostos na obra Phonemics: $a$ technique for reducing languages to writing de K. Pike, de 1947 - está em dotar o pesquisador (leia-se: missionário) dos chamados "procedimentos de descoberta"; um aparato que otimize o reconhecimento de quais são os "sons" distintivos, isto é, os fonemas, da língua em questão, permitindo o rápido avanço a níveis superiores de análise (morfológica e gramatical).

No entanto, gestado em um ambiente intelectual limitado e reprimido por um empirismo exacerbado e uma atitude francamente anti-mentalista, a Fonêmica sofre da mesma pobreza de recursos. Não admitindo a existência dos Sistemas Fonológicos propriamente ditos, a Fonêmica contenta-se com a "descoberta" dos "inventários fonêmicos". Não fazem parte das suas preocupações, buscar ou descobrir qualquer explicação para os "fatos" observados, e não cabem nesse "modelo" - dados os seus pressupostos filosóficos - quaisquer generalizações que ultrapassem um corpus constituído. A Fonêmica não só está na contramão das concepções que fundaram a Fonologia propriamente dita, pelo Círculo Linguístico de Praga, no final da década de 1920 (e, de igual forma, por isso, rompe com o legado do grande linguista teuto-americano, Edward Sapir), como se contrapõe, também, à concepção de língua como sistemas de oposições, que são a base da noção de valor do signo linguístico, na concepção de Saussure.

Um pesquisador que assuma a abordagem "fonêmica", não pode fazer afirmações (sobre a fonologia de uma língua que estude) tais como: "Nessa língua não são permitidas sílabas do tipo CVC". Em lugar disso, deverá afirmar, apenas: "Não foram observadas, no corpus, sílabas do tipo CVC". E como são empiristas, apegam-se aos fatos fonéticos, confundindo-os com a realidade fonológica (ou, para ser mais exato, reduzem a dimensão fonológica à realidade fonética). Além disso, raramente se dão conta de que o que entendem por "fato" ou "realidade fonética" é, também, fruto de seleções, seja da sua percepção de oitiva como falantes nativos de línguas indo-europeias ${ }^{30}$, seja de sua percepção etnocêntrica dos fatos fonológicos das outras línguas. ${ }^{31}$

As consequências das limitações da Fonêmica para as descrições fonológicas de línguas indígenas são muitas, sendo a mais comum, o fato de muitas dessas descrições apresentarem falhas gritantes, que se replicarão em escritas ortográficas igualmente falhas.

Recusando a noção de sistema fonológico e a concepção de valor de Saussure, a Fonêmica permanece nos marcos do que Trubetzkoy denominou "atomismo" da abordagem linguística do século XIX, e assume uma visão empirista e essencialista do fonema. Isso explica, por exemplo, porque, nas análises fonêmicas, "africadas" (quando ocorrem nas línguas) são descritas como "séries" separadas, mesmo quando uma tal "série" é constituída de um único elemento. A visão estreita presa à realidade fonética impede a maioria dos analistas da Fonêmica de observar as características e o comportamento comuns a esses elementos ("africados") e às demais obstruintes descontínuas do sistema (as "oclusivas"). E se o observa, o dogma empirista o impedirá de enunciar tal heresia.

Outro exemplo que merece ser lembrado é o tratamento típico das análises fonêmicas aos sistemas vocálicos. Curiosamente, em aparente contradição com um modelo tão empirista, é como se assumissem a existência real e universal das chamadas "vogais cardeais". ${ }^{22}$ Suponhamos, então, que em uma determinada

\footnotetext{
${ }^{29}$ Em D’Angelis (1998, p.281-283) enumero pelo menos 30 novos “modelos” ou “teorias” fonológicas aparecidos entre as décadas de 1970 e 1990 (à média de, praticamente, um por ano).

${ }^{30} \mathrm{O}$ treinamento fonético, se bem feito, pode minimizar bastante o efeito de "filtro" da língua materna, mas nunca o elimina completamente, a não ser em raros casos de pessoas excepcionalmente dotadas para esse trabalho.

${ }^{31}$ Trubetzkoy também já chamara a atenção para isso em seu artigo de 1933, acima referido.

${ }^{32}$ Não é demais lembrar que o sistema de vogais cardeais é um método de classificação exclusivamente fonética, não fonológica.
} 
língua sob análise, o pesquisador "praticante" da Fonêmica reconheça a existência da apenas quatro vogais (ou quatro fonemas vocálicos): i, e, o, a. Invariavelmente, uma análise fonêmica assim apresentaria o resultado dessa descoberta:

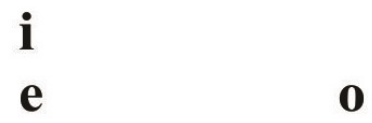

a

As vogais /i/ e /e/ seriam referidas como vogais anteriores, o /a/ como vogal central, e o /o/ como vogal posterior. No outro sentido, /i/ seria descrita como vogal alta ou fechada, /e/ e /o/ como vogais médias ou meio-fechadas, e /a/ como vogal baixa.

Aquela disposição e descrição supõem pontos fixos em um espaço imaginário, e um aprendizado ou aquisição, pelos falantes nativos, que distinga parâmetros acústicos absolutos. Nada disso se sustenta. Lidamos com jogos de oposições, e o que aprendemos ou adquirimos, ao aprender a fonologia de uma língua, são as diferenças, e não essencialidades. Se a língua em questão não possui uma oposição entre /u/ e /o/, então o /o/ é a vogal posterior alta do sistema (mesmo que, em relação a outras línguas, como a língua indo-europeia do pesquisador, a realização mais frequente, normal e comum, desta vogal, seja próxima ou idêntica ao que, em outro sistema, é um /o/ fonológico oposto a /u/). Lanço mão de uma analogia, em termos mais simples: numa comunidade mbyá guarani do Sul do Brasil um sujeito é descrito como "alto" se ele tiver entre 1,65 e 1,70 m. pelo menos. Em contrapartida, em uma comunidade de descendentes de imigrantes alemães, também no Sul do Brasil, um sujeito entre 1,65 e 1,70 m. de altura será descrito como "baixo".

No caso do exemplo acima, uma análise pragueana reconhecerá duas vogais anteriores (i, e) e duas vogais posteriores $(\mathbf{o}, \mathbf{a})$, sendo duas altas (i, o) e duas não-altas, ou baixas $(\mathbf{e}, \mathbf{a})$, e uma representação adequada desse sistema vocálico seria:

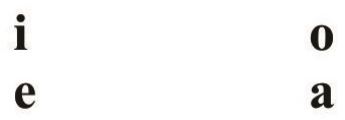

Alguns poderiam pensar que disso só resultam diferenças 'estéticas', quase um preciosismo, sem maiores consequências. Infelizmente não é assim. Em primeiro lugar, porque o único objetivo de se produzir análises fonológicas de línguas indígenas não é a criação de ortografias, e em muitos casos, efetivamente esse objetivo nem está em jogo. Interessa conhecer e compreender o funcionamento de distintos sistemas fonológicos para o desenvolvimento da própria ciência linguística, do que sabemos sobre as línguas humanas, dos modelos de análise fonológica e, na aplicação à linguística histórico-comparativa, para o estabelecimento de parentesco linguístico e para o estudo de processos diacrônicos de mudança linguística. Mas igualmente para os casos em que, da análise fonológica, se tiram os elementos para a definição de uma ortografia, dezenas de exemplos mostram que uma análise fonológica falha, porque não passou pelo crivo da noção de sistema, leva à formulação de uma ortografia que não responde ao desejável princípio da motivação fonológica.

Certamente não será uma análise fonológica com problemas e uma ortografia imprecisa que levarão uma língua indígena à obsolescência, enquanto o contrário seria uma condição de seu fortalecimento. Mas daí a aceitar que "qualquer coisa serve", desde que se possam alfabetizar as crianças indígenas na sua língua, parece-me uma atitude ainda calcada no preconceito que olha os povos indígenas e suas línguas como "mais simples", quando não, inferiores.

No entanto, desejo enfatizar que os maiores problemas causados pelas concepções da Fonêmica estão nos reflexos que essa formação tem nos consultores e docentes de cursos de formação de professores indígenas, e por consequência, no tipo de formação que se realiza com eles. Com isso, volto ao eixo central desse trabalho, no tópico seguinte. 


\section{O RISCO DE O PROFESSOR INDÍGENA SER UM MAU FONÓLOGO}

Pior do que o risco de alimentar, pelo treinamento fonético, a ideia de que a escrita transcreve a fala, é ensinar aos professores indígenas uma fonologia de base Fonêmica, na qual, como vimos, a dimensão fonológica é praticamente reduzida à Fonética.

Mencionei, como exemplo, o caso do tratamento das africadas, mas não é uma situação isolada. Se olharmos os quadros ditos fonológicos apresentados nas descrições de cunho fonêmico, de línguas indígenas, veremos que a nomenclatura para classificação dos fonemas é exatamente a mesma da fonética: oclusivas, fricativas, africadas, vibrantes, aproximantes (quando não escapa, ainda, um "semiconsoantes"), etc.; e como "pontos": bilabial, lábio-dental, dental, alveolar, pós-alveolar, palatal, etc. Isso gera inventários estranhos, nos quais, por exemplo, um /f/ não tem qualquer relação com um /p/ e um /b/ da mesma língua; um /t $\mathrm{f} /$ aparece não apenas separado das demais obstruintes, como um elemento à parte, mas também, na maioria das vezes, em uma coluna que não o associa, por oposição, a eventuais soantes (quer nasal, quer oral).

Parece oportuno lembrar aqui, o lúcido alerta de Jakobson:

[...] quanto mais o fonólogo se voltar para a abundância dos dados da fonética, tanto mais frutuoso será o seu trabalho; quanto mais substância fonética a fonologia experimentar e reelaborar, tanto melhor. Mas esses dados têm que ser realmente tratados de maneira fonológica; é preciso não trazer simplesmente para a fonologia o material fonético em seu estado cru, com pele e pelos por assim dizer (JAKOBSON, [1939] 1972, p.17).

Um professor indígena que aprenda e assuma aquele tipo de concepção, criticado no tópico anterior, não só julga que a escrita representa a fala, como passa a crer que a "letra" confunde-se com o fonema, e o valor fonético de uma letra é o valor de um fonema. Assume, com isso, uma concepção nuclear do "modelo": a biunivocidade. A um determinado fonema ("símbolo" ou "letra", no final das contas) correspondem determinadas características fonéticas, de modo que, ocorrendo o fonema, aquelas características tem que ser evocadas/realizadas; em contrapartida, a uma determinada combinação de características fonéticas corresponde um fonema, de tal modo que, se os traços fonéticos ocorrem, obrigatoriamente se deve assumir a ocorrência do fonema a que correspondem.

Exemplificando o tratamento "fonêmico", mencionei anteriormente o elucidativo caso do tratamento das vogais. Podemos lembrar aqui, então, o conhecido caso da língua quíchua (ou quechua), que possui apenas 3 vogais fonológicas (i, u, a), mas que na maioria das comunidades é escrita com um alfabeto que emprega 5 vogais $(\mathrm{i}, \mathrm{e}, \mathrm{u}, \mathrm{o}, \mathrm{a})$. Costuma-se dizer que isso se dá por exigência dos indígenas alfabetizados em espanhol.

Retomemos, também, um dos exemplos do kaingang apresentados acima, do processo pelo qual "nh" + "t" > $\left[\int\right]$. Como existe, na língua, um fonema / / / que por uma lamentável escolha de Wiesemann, se grafa com “s”), em sequências pronunciadas como [i'fว̃], [i'fũ $]$, [i'fãn] ou [i'fว̃n] a concepção "fonêmica” leva à conclusão de que o "s" deve ser escrito, porque se trataria da presença do fonema. ${ }^{33}$ Isso rompe, seja com a ideia de motivação fonológica, seja com um princípio morfológico que, com frequência, também se emprega na definição das regras ortográficas de uma língua. Assumir essa concepção permitiria (ou exigiria?), numa língua como o português, escrever coisas como: "quiquiéissu", "Santantônio", "déizimeia", etc. ${ }^{34}$ Quanto se pensa em tais exemplos, no português, é a tradição escrita e o letramento que nos faz estranhar as sugestões, e recusá-las. Mas quando se trata de línguas indígenas, sem tradição escrita, o princípio da biunivocidade ("uma vez fonema, sempre fonema") não somente se aplica sem hesitação, como os próprios assessores/consultores encontram dificuldade em argumentar contra sua aplicação.

As causas dos problemas mencionados não podem ser resumidas, porém, à formação acadêmica dos docentes e a reprodução do modelo fonêmico. Há vários linguistas, ${ }^{35}$ entre os que colaboram com

\footnotetext{
${ }^{33}$ Por esse raciocínio, em português teríamos que escrever coisas como "dezde", "razga”, "azma”, etc. porque o som que efetivamente se realiza no final da primeira sílaba, nesses exemplos, é um [z], o que deveria significar a presença do fonema. Essa é a solução coerente com os fundamento da Fonêmica.

${ }^{34}$ Isso lembra um caso curioso, bastante recente: em 2012, quando da realização dos Jogos Paraolímpicos no Brasil, o Comitê Olímpico brasileiro mudou o nome da competição para "Jogos Paralímpicos" (e, obviamente, a imprensa acompanhou, dada nossa tradição autoritária); a alegação foi de que a palavra "paraolímpico” é propriedade (!) do Comitê Olímpico Internacional.

${ }^{35}$ Gostaria de poder escrever "muitos linguistas”, mas não é o que acontece.
} 
programas de formação de professores indígenas, que não trabalham nem ensinam aquele modelo. No entanto, trata-se de uma matéria realmente difícil de tratar em termos simples, e sua compreensão já é difícil (e, para alguns alunos, impossível) entre os estudantes falantes nativos de português, nos cursos de Letras. Não se tire, daqui, a conclusão de que estou sugerindo que professores indígenas têm maior dificuldade para estudar Fonologia ou para envolver-se em reflexões mais abstratas, do que seus colegas não-índios, só por serem indígenas. Ignorar, no entanto, as dificuldades específicas que enfrentam os indígenas na formação superior, seria assumir uma atitude populista, que se confunde ou se baseia numa postura paternalista (e, portanto, colonialista). É preciso reconhecer as grandes dificuldades dos professores indígenas em formação, quando são falantes nativos de suas línguas (e, portanto, aprenderam e usam o português como sua $2^{\mathrm{a}}$ língua) e, em sua grande maioria, raramente desenvolveram hábitos de leitura (ou tiveram oportunidade para tal) ao longo do ensino fundamental. Isso produz uma diferença de "capital linguístico e cultural” (remetendo a Pierre Bourdieu) que não pode ser desconsiderada.

Da dificuldade de lidar com os conceitos abstratos da Fonologia, ao lado de um certo apego à "realidade" e à "transparência" fonética, resultam outros tantos problemas para a percepção dos indígenas com respeito à escrita de suas línguas. Um problema sério, que igualmente observei entre os kaingang, tem semelhança com o fato relatado, anteriormente, entre os ashaninka. Professores kaingang, bilíngues e alfabetizados em português, têm conhecimento, obviamente, da existência de "sons" como [b], [d] e [g], no português, e de sua representação na escrita pelas letras "b", "d" e g". Quando tomam contato com a representação fonética,

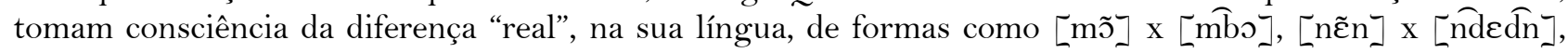
[ỹ̃ũ $]$ x [ygru $]$. Fonologicamente, a distinção fundamental, em cada um desses pares de palavras, é

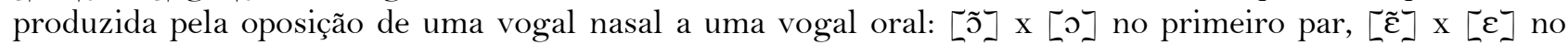
segundo, e $[\tilde{u}] \mathrm{x}[\mathrm{u}]$ no terceiro. Isso fica mais evidente quando se comparam as formas fonológicas e ortográficas respectivas:

\begin{tabular}{|c|c|c|c|}
\hline “ $\mathrm{n}$ & $\mathrm{x}$ & /mo/ "mó" & jabuticaba $\mathrm{x}$ espiga ${ }^{36}$ \\
\hline /nẽn/"nẽr & $\mathrm{x}$ & /nen/"nén” & mato ralo 37 x coisa \\
\hline /yrũ / “grũ” & $\mathrm{x}$ & /yru/ "gru" & tucano $\times$ aceso \\
\hline
\end{tabular}

O processo fonológico que produz um "contorno" desnasalizado na consoante nasal ${ }^{38}$ visa preservar a importante oposição entre vogais orais e nasais do kaingang. O processo gera uma pista secundária, ao ouvinte, a respeito da vogal presente na sílaba e, portanto, contribui ao reconhecimento da palavra. Porém, como todo processo dessa ordem, essa contribuição e essa pista secundária são tomadas ou percebidas de modo inconsciente pelos falantes e ouvintes. De modo semelhante, por exemplo, um falante naïve do português não tem consciência de que suas vogais tônicas são foneticamente alongadas, mas essa é uma pista acústica importantíssima (embora secundária) para a percepção da tonicidade em português. ${ }^{39}$

O fato de o "contorno" desnasalizado ser uma característica fonética secundária no kaingang se evidencia no processo de alfabetização: nenhuma criança encontra dificuldades ou coloca dúvidas por empregar, por exemplo, a mesma letra "m" tanto em palavras nasais como "mỹ" (para, Dat.), quanto em palavras orais como "my" (rabo), embora a forma fonética da consoante seja distinta de uma para outra palavra: respectivamente, $[\mathrm{m}]$ e $[\mathrm{mb}]$. É o mesmo que observamos com crianças falantes de dialetos do português que produzem africação de $/ \mathrm{t} / \mathrm{e} / \mathrm{d} /$ diante de "i”, gerando as pronúncias [t $\mathrm{i} i]$ e [dzi]; nenhum alfabetizando encontra dificuldade ou põe dúvidas em escrever com a mesma letra "t", tanto as sílabas "ta", "te", "to" e "tu", quanto a sílaba "ti".

\footnotetext{
${ }^{36}$ A diferença da vogal, entre a forma escrita e a forma fonológica na palavra “jabuticaba”, deve-se ao fato de que estou empregando um par mínimo conforme ocorre em dialetos de Santa Catarina e Rio Grande do Sul, enquanto que a forma escrita está baseada no dialeto do Paraná.

${ }^{37}$ Também nesse caso a forma empregada segue o uso das comunidades mais ao Sul (e a nossa posição de que tais formas precisam ter representação ortográfica). A forma escrita padronizada é "nãn” (mato), no entanto, em algumas comunidades mantém-se uma distinção valiosíssima e culturalmente ancorada, entre "grosso, forte, baixo, compacto" (para as quais se empregam formas com [ ̃̃]) e "fino, delicado, alto, difuso" (para as quais se empregam formas com [ $[\tilde{\varepsilon}])$. Veja-se, sobre isso, D'Angelis (2002).

${ }^{38}$ Nos exemplos: /m/ > [mb]; /n/ > [nd $] ; / \mathrm{n} />[\mathrm{dn}] ; / \mathrm{h} />[\mathrm{gg}]$.

${ }^{39}$ Pode haver controvérsia com respeito ao caráter secundário do papel do correlato acústico de duração na percepção da tonicidade em português. A escolha do exemplo se deu, porém, por facilitar a compreensão das operações inconscientes executadas no reconhecimento da fala.
} 
No entanto, há professores kaingang que, uma vez tendo estudado Fonética, por mais que se busque distingui-la da Fonologia, volta e meia colocam a questão de "melhorar" ou "adequar" a escrita, pensando em grafar formas como "mb", "nd" e "ng" (que não são fonemas na sua língua).

\section{FONÉTICA E FONOLOGIA NA FORMAÇÃO DO PROFESSOR INDÍGENA}

Algumas páginas atrás, em rodapé, mencionei que há uma outra motivação que leva docentes dos cursos de formação de professores indígenas a ministrar Fonética e Fonologia nesses cursos, que não apenas o modelo dos cursos de Letras das melhores Universidades. O motivo é que, muitas vezes, o próprio linguista docente não possui, ainda, uma boa análise fonológica da língua. Isso se dá, quer porque seus estudos da língua ainda são inconclusivos em alguns aspectos, ou porque, embora estude e trabalhe com a língua em questão, assuma uma análise fonológica feita por outro pesquisador que a estudou antes dele. Ou, ainda, porque se trata de ministrar cursos a falantes de uma língua que ele jamais estudou.

Essa última situação não é tão incomum quanto pareça. Exemplifico com uma experiência própria, da qual quero tirar, em seguida, propostas para o trabalho em Fonética e Fonologia em cursos de formação de indígenas.

No segundo semestre de 2004, por razões que desconheço, o Curso de Formação de Professores para o Magistério Indígena, na Rondônia (Projeto Açaí), encontrou dificuldades para dar sequência às disciplinas de linguística com alguns linguistas que normalmente atuavam como seus assessores. Um colega pedagogo, que atuava no Curso, sugeriu meu nome, para uma situação de emergência, e fui convidado (com um mês de antecedência) para atuar em uma Etapa do curso, no caráter de excepcionalidade. Durante 6 dias eu deveria trabalhar fonética e fonologia em uma turma com pouco mais de 30 alunos, falantes de 8 línguas, ${ }^{40}$ de 7 famílias linguísticas diferentes. E nenhuma delas fora, até então, objeto de minhas pesquisas (minha única 'familiaridade' anterior com alguma delas, se devia ao meu conhecimento da língua guarani falada no Sul do Brasil, que me dava algum ponto de contato com amondawa e uru-eu-wau-wau). ${ }^{41}$

Entendi, já pelos coordenadores, que para muitos desses professores o que se colocava eram dúvidas com relação à escrita e, algumas vezes, à adequação do alfabeto. Já no curso, no contato com eles, percebi que os incômodos mais comuns e relevantes dos indígenas não provinham de um curso de Fonética e Fonologia, tal qual questionei acima, mas provinham de sua intuição de falantes nativos no uso de alfabetos que lhes foram "presenteados" ou impostos. Como anotei em relatório, na época, consultando-os sobre suas expectativas e interesses, "a maioria mencionou preocupações e dúvidas a respeito da escrita de sua língua ou suas dificuldades para usar a escrita corrente dela, em razão de dúvidas no emprego de certos símbolos".

Como disse, não creio que situações assim sejam tão incomuns. Em um contexto como esse, ou mesmo quando todos os cursistas sejam falantes de uma mesma língua indígena, da qual o linguista-docente não seja falante, penso que alguns linguistas recorrem ao ensino da Fonética para, na sequência, usar esse conhecimento compartilhado com os falantes nativos para assegurar-se da correção da sua própria transcrição fonética. Isso suporia, pelo menos, que o docente fosse um excelente professor de fonética articulatória, o que também nem sempre é o caso, sobretudo quando ele próprio tem dificuldades com transcrição. No caso em que tudo conspire a favor, e os indígenas sejam bem treinados em transcrição fonética, o ganho efetivo, para o trabalho com a língua indígena, na verdade é muito pequeno, e as chances de surgirem problemas são bem maiores. Isso porque, para contar com a intuição fonológica do falante nativo, o melhor é garantir que ela não seja influenciada pela reflexão e conhecimento consciente. Já um falante nativo que, por treinamento, seja capaz de transcrever foneticamente sua língua de forma muito precisa, só contribuirá, ao linguista, com a qualidade da transcrição fonética; quanto ao nível fonológico, ou isso nada agregará, ou levará o falante nativo a assumir o equívoco de tomar a "realidade" fonética como "a verdade" da língua.

\footnotetext{
${ }^{40}$ Aikanã, amondawa, karitiana, kaxarari, nambikwara, oro (ou oro wari'), tupari e uru-eu-wau-wau.

${ }^{41}$ Em outra oportunidade, no Acre, em 2010, ministrei curso para uma turma de quase 40 alunos, falantes de 3 línguas diferentes: manxineri, madiha (kulina) e ashaninka (das quais, apenas o última era objeto de algum trabalho meu). Alguns deles não falavam português, mas podíamos nos comunicar em espanhol, e outros dependiam totalmente de colegas bilíngues.
} 
Não se está, aqui, advogando a ideia de manter os indígenas na "ignorância" da análise linguística, como forma de garantir uma "pureza" de dados. O que se tem que entender é que ser Fonólogo é uma especialização que não se adquire em minicursos ou frequentando uma disciplina. Esse, aliás, é um dos preconceitos que levam a Fonologia de línguas indígenas ao estado atual em nosso país: uma confusão que se faz, talvez até por razões terminológicas, entre o fato de a Fonologia ser tomada como o "primeiro nível" de análise, e como tal, ser destinada aos estudantes em sua primeira aproximação à língua indígena. Inferese, disso, que Fonologia é coisa para linguista iniciante, e que a análise fonológica de uma língua indígena é algo que um estudante de Mestrado (quando não, de Iniciação Científica) “dá conta”.

Ao contrário de alimentar, nos professores indígenas, a ilusão da "transparência" de uma escrita fonética, a disciplina de Fonética e Fonologia, em cursos para aqueles professores, deve priorizar:

1. a desmistificação da "transparência" da letra, revelando-se sua arbitrariedade. Muitos indígenas creem, ingenuamente, que a "letra" é a contraparte necessária e exata do som da fala, de modo que, consequentemente, não percebem que um linguista propõe um alfabeto e uma ortografia; ao contrário, acreditam que ele "extrai" ou "revela" o que está presente, mas escondido, na língua. Muitos indígenas se surpreendem quando entendem que a escrita de sua língua foi produzida com escolhas (humanas), que podem ser alteradas por outras escolhas.

Não é demais ressalvar que a "arbitrariedade" da letra, como signo fônico, não é absoluta, em dois aspectos: o primeiro, no mesmo sentido em que a arbitrariedade é limitada, na própria concepção de Saussure (o linguista que formulou, por primeira vez, essa ideia), ou seja, um primeiro signo pode ser qualquer coisa, mas os seguintes já dependem das relações (de oposição) que estabelecem com os anteriores. O segundo sentido, pela qual uma letra não é totalmente arbitrária é o fato de que a definição do alfabeto de uma língua indígena não desconsidera a existência histórica dos alfabetos em outras línguas, e sobretudo, não pode desconsiderar a existência do alfabeto da língua majoritária (oficial) do país, cuja escrita os indígenas também desejam aprender e utilizar. Um exemplo de escolha arbitrária infeliz, exatamente por desconsiderar esse último aspecto, é a letra "s" da escrita do kaingang, com o valor de $/ \mathrm{f} /$, o mesmo valor para o qual, em português, usamos dois recursos: o "x" e o "ch". Além de desconsiderar esse fato, a escolha de "s" para / / / do kaingang, ainda desconsidera o fato de que a letra "s" já cria outros problemas para os aprendizes da escrita do português (mesmo os falantes nativos), tanto porque ela mesma pode representar dois fonemas distintos $(/ \mathrm{s} / \mathrm{e} / \mathrm{z} /$ ), quanto porque o fonema /s/ tem, naquela letra, apenas uma das suas representações ortográficas, podendo também ser grafado com "c", "çc" e "ss". ${ }^{42}$

2. a desmitificação do linguista (ou missionário) como o poderoso decifrador da língua. Muitos indígenas se surpreendem ainda mais, quando descobrem que o linguista (ou o missionário) não é dono da escrita da língua deles, e que eles mesmos podem decidir modificá-la.

3. a desmitificação da "grandeza" ou "superioridade" da língua dominante, isto é, do português, por sua história e pela história da sua escrita. Muitas comunidades indígenas que experimentam situações de perda linguística (em qualquer medida), ou sentem sua língua enfraquecer diante do embate com a língua majoritária, ganham ânimo ao descobrirem que seus colonizadores (portugueses, no Brasil; espanhóis, no restante da América Latina) são povos que outrora foram dominados, a tal ponto que abandonaram completamente a língua de seus ancestrais. Ou seja, que a poderosa língua que hoje falam é uma derivação da língua dos romanos colonizadores da Península Ibérica, e que em termos de idade, não chega a 1.000 anos, uma profundidade temporal bem menor do que aquela calculada para muitas línguas indígenas brasileiras. Conhecer, por outro lado, a história da escrita dessas línguas, em seus diversos momentos, com suas idiossincrasias e suas incongruências, revela aspectos comuns das histórias das criações ortográficas e, ao mesmo tempo, a imperfeição da escrita da língua dominante.

4. a descoberta e a compreensão, por eles, do valor da intuição do falante nativo na avaliação das escritas ortográficas que lhes foram outorgadas. Com isso, valoriza-se também a experiência deles como alfabetizadores, pela observação privilegiada que podem fazer, das escritas iniciais de seus jovens alunos.

${ }^{42}$ Por razões que não vêm ao caso, aqui, não considero "xc" e "sc" como dígrafos, como fazem muitos autores. 
5. a compreensão das interferências previsíveis, no uso da $2^{\mathrm{a}}$ língua (na oralidade e na escrita), de recursos da $1^{a}$ língua, e vice-versa. Isso não se restringe ao campo da fonologia (na fala e na escrita), porque também se reflete na morfologia, sintaxe, semântica e pragmática, mas nosso foco, aqui, é o dos sistemas fonológico e ortográfico. Para isso, indiscutivelmente, o professor terá que alcançar algum conhecimento de fonética e, principalmente, de fonologia. Só assim poderá entender - e, dessa forma, ajudar seus alunos - porque, por exemplo, é comum que eles pronunciem (e escrevam) com " $r$ " palavras do português que são faladas e escritas com "l”; ou, porque uma criança kaingang escreve com "m" uma palavra que, no português, emprega um "b". Também poderá entender porque, na altura da $3^{\mathrm{a}}$ ou $4^{\mathrm{a}}$ série, alunos seus escrevam palavras da língua indígena com "gu", quando a forma correta é com "w”; ou com "nh" quando, na escrita da sua língua materna, se usa um "j" ou um "y".

Retomando minha experiência da Rondônia, para com isso ilustrar - e encerrar - essas sugestões, o que fiz lá foi, em síntese, o que relato abaixo.

No primeiro dia pedi a eles para responderem a um pequeno questionário, com perguntas sobre a situação sociolinguística de suas comunidades, no qual a última questão era: "Qual é sua maior dificuldade quando vai escrever na sua língua?” As respostas foram muito objetivas, como por exemplo:

- $\quad$ H com som R, K com som C. - (aikanã)

- dúvida ao escrever palavras com vogais longas - (karitiana)

- gng, mp ou nt (dúvidas) - (karitiana)

- não entendo porque houve mudança de letras (txu que tem som ru) - (nambikwara)

- últimos 5 anos houve mudança da letra: T com D, N com M. - (nambikwara)

- dificuldade é troca de palavras, quando tem palavra com acento glotal - (oro)

- letras B, M, K, Y-(oro).

Em outro momento, na sequência do curso, pedi que listassem as principais dificuldades dos seus alunos no escrever a língua indígena, especificando, inclusive, "quais letras eles mais erram? (trocas, esquecimentos)". Ao mesmo tempo, pedia que informassem se essas crianças eram alfabetizadas em língua indígena ou em português (por conta dos previsíveis problemas referidos no ítem n. 5, logo acima).

Organizamos o trabalho, então, de modo que tínhamos atividades em comum, com destaque para as sessões de teorização, mas no período noturno, a cada dia mantive duas sessões de trabalho exclusivamente com os falantes de uma determinada língua, enquanto os demais realizavam tarefas agendadas em grupo.

Meu objetivo não era fazer uma análise fonológica de cada língua, muito menos "obter dados" de pesquisa (como costuma acontecer, também, em muitos cursos), mas eu necessitava de uma análise para avaliar (com eles) a adequação do seu sistema de escrita e ajudá-los, assim, nos problemas que eles apresentavam. Por isso,

com todos os grupos de falantes de cada língua, o primeiro passo do trabalho específico foi estabelecer, para mim, uma hipótese sobre o sistema fonológico da língua. Em primeiro lugar, significava reconstruir, a partir do alfabeto, o que a perspectiva fonêmica chamou de "inventário fonêmico" ${ }^{43}$ : pedir aos professores para apresentar-me as letras e seus respectivos "sons" (valores fonéticos). Depois disso minhas inquirições se voltavam ao padrão silábico e às restrições de ocorrência de determinadas letras em cada posição. Por fim, voltava-se muitas vezes diretamente a uma letra específica, tentando confirmar distintas hipóteses sobre seu estatuto fonológico, a partir da hipótese que já então construíra sobre o sistema como um todo. Depois, ou ao longo desse diálogo, ia apresentando aos professores as hipóteses que se iam fortalecendo e suas consequências para a escrita, e sugerindo que eles pensassem sobre elas.

\footnotetext{
${ }^{43}$ Isso não significa que eu estivesse assumindo tão limitada perspectiva de análise fonológica; ao contrário. Mas para chegar à minha análise, o caminho mais rápido era estabelecer o inventário que, na maior parte dos casos, foi efetivamente o que fizeram os missionários ou linguistas que definiram as escritas dessas línguas. [ ...] - Nota original do texto citado.
} 
Depois disso é que passávamos a questões morfológicas e de ordem de constituintes. (D’ANGELIS, 2004c, p. 6).

Para citar alguns exemplos das reanálises que se tornaram possíveis, e foram compartilhadas com os professores em formação, sugerindo-lhes um estudo com mais demora, anoto, do meu Relatório da disciplina:

- a probabilidade de que "h" e oclusiva glotal (' ), em oro wari', sejam variantes posicionais;

- a probabilidade de que “v" e “w”, no aikanã, não representem dois fonemas distintos, mas apenas variantes.

- um “z̃”, que a escrita do aikanã empregava em diversas palavras, revelou-se uma realização de “z” em contexto de vogal nasal (muitas vezes, não registrada como tal).

- a possibilidade de que algumas ocorrências da variante [ $\phi]$ (que eles diziam ser um “f”) da consoante "p", aparentemente não explicadas, estejam associadas a uma estrutura silábica CCV, com um "w" ocupando a segunda posição de ataque.

E concluo a "ilustração" do caso, com outra anotação de citado Relatório, que corrobora o que foi dito neste texto sobre os malefícios, para a escrita de uma língua indígena, de uma análise fonológica ruim:

de todos os grupos, os karitiana demonstraram mais dificuldades com sua alfabetização (ou mais casos de 'desvios' das crianças à ortografia atual da língua), fruto das dificuldades de uma escrita que é quase transcrição fonética na maior parte dos casos, com bem pouca 'abstração' fonológica. (D’ANGELIS, 2004:6).

O presente estudo, antes que propor um programa bem amarrado para a abordagem da Fonética e da Fonologia na formação de professores indígenas, traz elementos para avaliação dos problemas gerados pela replicação, naquele contexto, de práticas desenvolvidas em uma situação muito distinta: a das línguas majoritárias, com larga tradição escrita. Reunindo exemplos de muitas situações reais experienciadas (outras tantas, semelhantes, sequer foram mencionadas), e levantando sugestões para o desenvolvimento de algumas possíveis experiências inovadoras, esperamos que a reflexão contribua, de uma forma ou outra, para o aperfeiçoamento dessas disciplinas nas Licenciaturas específicas para povos indígenas.

\section{REFERÊNCIAS}

CAGLIARI, Luiz Carlos. Alfabetização E̊ Linguística. São Paulo: Scipione, 1989.

D’ANGELIS, Wilmar R. Conquistar ou construir a escrita? A definição de uma ortografia no ashaninka do Rio Amônia. Leitura: teoria E̊ prática, Campinas: ALB; Porto Alegre: Mercado Aberto, n. 24, p. 3-19, 1994.

Traços de modos e modos de traçar geometrias: línguas Macro-Jê छ̊ teoria fonológica. 420p.Tese

(Doutorado em Linguística) - IEL, UNICAMP, Campinas, 1998.

Gênero em kaingang? In: SANTOS, Ludoviko; PONTES, Ismael (Orgs.). Língua Jê: estudos vários. Londrina: Ed. UEL, 2002. p. 215-242.

. O SIL e a redução da língua kaingang à escrita: um caso de missão 'por tradução'. In: WRIGHT, Robin (Org.). Transformando os deuses. Vol. II: Igrejas evangélicas, pentecostais e neopentecostais entre os povos indígenas no Brasil. Campinas: Ed. da UNICAMP, 2004a, p. 199-217.

. O alinhamento pró-Estados Unidos da Fonologia no Brasil. Revista Brasileira de Linguística

Aplicada, Belo Horizonte: FALE-UFMG, v. 4, n. 1, p. 87-115, $2004 \mathrm{~b}$.

Línguas Indígenas precisam de escritores? Como formá-los? 1. ed. Campinas, SP: Cefiel - IEL UNICAMP, 2005. v. 1; 48p .

Unificação x Diversificação Ortográfica: um dilema indígena ou de linguistas? In: RODRIGUES, Aryon D.; CABRAL, Ana Suelly A.C. (Orgs.). Novos estudos sobre línguas indígenas. Brasília: Ed. da UnB, 2005. p. 23-33. 
Sistema vocálico e escrita do kaingang. In: RODRIGUES, Aryon D.; CABRAL, Ana Suelly A.C.

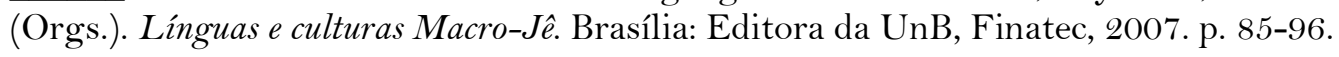

. Aprisionando sonhos: a educação escolar indígena no Brasil. Campinas: Ed. Curt Nimuendajú, 2012.

EDELWEISS, Frederico G. O valor do "S" e do "Ç" no português antigo. In:

Tupis e Guaranis.

Estudos de Etnonímia e Linguística. Salvador, BA: Museu da Bahia, 1947. p. 85-86.

ILARI, Rodolfo. A Linguística e o ensino da Lingua Portuguesa. São Paulo: Martins Fontes, 1985.

JAKOBSON, Roman. Para a estrutura do fonema. In: . Fonema e Fonologia. Trad. J. Mattoso Câmara Jr. Rio de Janeiro: Livraria Acadêmica, 1972. p.15-52.

MAIA, Marcus. Manual de Lingüística: subsídios para a formação de professores indígenas na área de linguagem. Brasília: MEC-SECAD; Rio de Janeiro: LACED-Museu Nacional, 2006.

MARTIN, Robert. O escrito como espaço de convenções. In: CATACH, Nina (Org.). Para uma teoria da língua escrita. Trad. Fulvia Moretto e Guacira Machado. São Paulo: Ática, 1996. p. 53-63.

SAPIR, Edward. A realidade psicológica dos fonemas [1933]. In: DASCAL, Marcelo (Org.). Fundamentos metodológicos da linguística. Vol. II - Fonologia e Sintaxe. Campinas, SP: Ed. do Organizador, 1981. p. 37-55.

SAUSSURE, Ferdinand de. Curso de Linguística Geral. 6. ed. Trad. Antonio Chelini et al. São Paulo: Cultrix, 1974 .

TRUBETZKOY, Nikolay. A fonologia atual [1933]. In: DASCAL, Marcelo (Org.). Fundamentos metodológicos da linguística. Vol. II - Fonologia e Sintaxe. Campinas, SP: Ed. do Organizador, 1981. p. 15-35.

Recebido em 11/11/13. Aprovado em 19/12/13. 